\title{
Color Stability of NeoMTA Plus and MTA Plus when Mixed with Anti-washout Gel or Distilled Water
}

\author{
Çözünmeye Dirençli Jel veya Distile Suyla Hazırlanan NeoMTA \\ Plus ve MTA Plus Materyallerinin Renk Stabilitelerinin \\ Değerlendirilmesi
}

\author{
(1) Cangül Keskin ${ }^{1}$, (1) Evren Sarıyılmaz ${ }^{2}$ \\ ${ }^{1}$ Ondokuz Mayıs University Faculty of Dentistry, Department of Endodontics, Samsun, Turkey \\ ${ }^{2}$ Ordu University Faculty of Dentistry, Department of Endodontics, Ordu, Turkey
}

Keywords

Discoloration, MTA Plus, NeoMTA Plus, spectrophotometer

Anahtar Kelimeler

Renklenme, MTA Plus, NeoMTA Plus, spektrofotometre

Received/Geliş Tarihi : 07.09.2017

Accepted/Kabul Tarihi : 06.02.2018

doi:10.4274/meandros.60362

Address for Correspondence/Yazışma Adresi: Cangül Keskin $\mathrm{PhD}$,

Ondokuz Mayıs University Faculty of Dentistry, Department of Endodontics, Samsun, Turkey

Phone : +905414203909

E-mail : canglkarabulut@gmail.com

ORCID ID: orcid.org/0000-0001-8990-4847

(C) Meandros Medical and Dental Journal, Published by Galenos Publishing House.

This is article distributed under the terms of the Creative Commons Attribution NonCommercial 4.0 International Licence (CC BY-NC 4.0).

\begin{abstract}
Objective: This study aims to evaluate the effect of the special anti-washout gel mixing agent on the color stability of mineral trioxide aggregate (MTA) Plus and NeoMTA Plus in contact with distilled water, ethylenediaminetetraacetic acid (EDTA) and sodium hypochlorite ( $\mathrm{NaOCl})$.

Materials and Methods: One set of three specimens was mixed using the antiwashout gel and the other set of three specimens was mixed using distilled water. Then, one specimen from each group was immersed in distilled water, $5 \% \mathrm{NaOCl}$ or EDTA solutions for 24 hours. The color change of each specimen was assessed using spectrophotometer. The data were evaluated statistically with two-way ANOVA and post-hoc Tukey tests.

Results: It was found that there was no statistically significant differences among the color changes of the MTA Plus and NeoMTA Plus mixed with either distilled water or gel when immersed in distilled water and EDTA ( $p>0.05)$. Immersion to $\mathrm{NaOCl}$ resulted in the highest discoloration in all materials compared to their immersion to distilled water and EDTA. MTA Plus mixed with distilled water showed significantly greatest discoloration after contact with $\mathrm{NaOCI}(p<0.05)$. MTA Plus mixed with gel showed the highest color stability regardless of the solution type. Conclusion: Mixing with MTA Plus and NeoMTA Plus powder with the special antiwashout gel within their kits contributes to the color stability of the materials.
\end{abstract}

Öz

Amaç: Bu çalışma, özel çözünme direnci sağlayan jel karıştırma ajanlarının mineral trioksit agregat (MTA) Plus ve NeoMTA Plusın renk stabilitelerine etkisini materyallerin distile su, etilendiamintetraasetik asit (EDTA) ve sodium hipoklorit $(\mathrm{NaOCl})$ temasları sonrası değerlendirmeyi amaçlamaktadır.

Gereç ve Yöntemler: Her iki materyalden üç numune içeren bir set çözünmeye dirençli jel kullanılarak, diğer set ise distile su kullanılarak hazırlandı. Daha sonra, her setten birer numune 24 saat boyunca distile su, \% $55^{\prime}$ lik $\mathrm{NaOCl}$ veya EDTA solüsyonları içerisinde tutuldu. Her materyalde meydana gelen renk değişikliği 
spektrofotometre kullanılarak değerlendirildi. Veriler iki-yönlü ANOVA ve post-hoc Tukey testleri kullanılarak istatistiksel olarak değerlendirildi.

Bulgular: MTA Plus ve NeoMTA Plus materyalleri jelle veya distile suyla karıştırılıp hazırlandıklarında distile su ve EDTA ile temasları sonucu meydana gelen renk değişiklikleri arasında istatistiksel olarak anlamlı fark olmadığı bulundu $(p>0,05)$. $\mathrm{NaOCl}$ da bekletilen örneklerin tamamında distile su ve EDTA içinde bekletilen örneklere kıyasla yüksek renklenme görüldü. Distile su ile hazırlanan MTA Plus, $\mathrm{NaOCl}$ ile temas sonrası en yüksek renk değişimini gösterdi $(p<0,05)$. Jel ile karıştırılan MTA Plus bekletildiği solüsyon tipinden bağımsız olarak en yüksek renk stabilitesini gösterdi.

Sonuç: MTA Plus ve NeoMTA Plus tozlarının ürün kitlerindeki özel çözünme engelleyici jelle karıştırımaları materyallerin renk stabilitelerine katkı sağlamaktadır.

\section{Introduction}

Discoloration of dental structures following application of endodontic materials is an unpleasant matter that harms treatment quality and patient satisfaction. The exact mechanism behind the discoloration following endodontic procedures is not known, yet. Material penetrations into the dentinal tubules and reflection of discoloration through hard tissues have been indicated as the principal mechanisms of tooth discoloration over time $(1,2)$. Therefore, material selection to be used in the aesthetic zone is crucial to prevent further discoloration.

Mineral trioxide aggregate (MTA) includes bismuth oxide and modified Portland cement (3). MTA has been utilized for many endodontic procedure including pulpotomy, pulp capping, perforation repair, apexification, (4) and revascularization procedures (5). Since previous case reports associated the use of grey MTA with coronal tooth discoloration $(6,7)$, white MTA was developed (8). Nevertheless, discoloration within the mass of wProRoot MTA (9) and tooth discoloration has also been reported $(10,11)$.

Bismuth oxide within the MTA and MTA-like materials' composition has been associated with tooth discoloration, which has led to the invention of different materials with similar compositions that will not induce discoloration. MTA Plus (Avalon Biomed Inc, Bradenton, FL, USA) is a cost-effective, tricalcium silicate-based MTA-like material developed for similar indications to MTA. MTA Plus has been reported to have smaller particle sizes when compared to MTA (12). The MTA Plus kit consists of MTA Plus powder and a gel, which provides washout resistance to the setting material. Recently, the manufacturer of MTA
Plus marketed NeoMTA Plus for the aesthetically important areas by changing the bismuth oxide with tantalum oxide within its composition. NeoMTA is also mixed with MTA Plus gel within the kit.

Powders of MTA and MTA-like materials can also be mixed with distilled water and local anaesthetic agents due to the depletion of liquids/gels before powder. Manufacturer provides these materials with either water or gel for mixing (12). The aim of this study was to evaluate the effect of anti-washout gel on the color stability of MTA Plus and NeoMTA Plus in contact with different irrigation solutions.

\section{Materials and Methods}

\section{Specimen Preparation}

The study did not include any human or animal information, tissue or material. Thus, no ethical approval was required. Two groups of materials were used in this study as MTA Plus and NeoMTA Plus with each group containing 3 specimens. All materials were mixed homogeneously according to the manufacturers' instructions. One group was mixed using the anti-washout gel and the other group was mixed using distilled water. Cylindrical specimens, $5 \mathrm{~mm}$ in diameter and $2 \mathrm{~mm}$ high, were obtained by curing them in molds according to each material's setting time at $100 \%$ humidity and $37{ }^{\circ} \mathrm{C}$. The specimens mixed with gel were incubated for 60 minutes, whereas specimens mixed with distilled water were incubated for 5 hours, as suggested by the manufacturer. Then, the setting of each specimen was controlled and the specimens were separated from the molds. One specimen from each group was immersed in the following three irrigation solutions for 24 hours: distilled water, 5\% sodium hypochlorite $(\mathrm{NaOCl})$ solution (Wizard, Ankara, Turkey) or $17 \%$ 
ethylenediaminetetraacetic acid (EDTA) (Werax, Ankara, Turkey). After 24 hours of immersion, the specimens were dried and the colors of each were assessed before and after immersion. The study did not include any human. Thus, informed consent was not required.

\section{Spectrophotometric Analysis}

Spectrophotometer (VITA Easyshade ${ }^{\circledR}$ compact; VITA Zahnfabrik, Bad Sackingen, Germany) was utilized to calculate total color change under constant conditions (same laboratory light and the same operator). Prior to each measurement the device was calibrated. Each measurement was repeated three times and the mean value was calculated. The Commission Internationale de l'eclairage (CIE) system was utilized to calculate the differences in color.

The color differences of the samples were calculated by using the following formula:

$$
\Delta \mathrm{E}=\left[(\Delta \mathrm{L})^{2}+(\Delta \mathrm{a})^{2}+(\Delta \mathrm{b})^{2}\right] \frac{1}{2}
$$

$\Delta \mathrm{L}$ represents the change in luminosity, $\Delta \mathrm{a}$ represents the change in red-green parameter and $\Delta b$ represents the change in yellow-blue parameter. $\Delta \mathrm{E}$ values, which were equal to or greater than 3.3 were accepted as clinically perceptible discoloration (13).

\section{Statistical Analysis}

The data were evaluated with two-way ANOVA by using SPSS software (PASW Statistics 20.0; SPSS Inc, Chicago, IL, USA). The significant effects and interactions were further investigated with post-hoc
Tukey test. The level of statistical significance was set at $p<0.05$.

\section{Results}

The mean values for changes in color of materials are presented in Table 1. Distilled water and EDTA caused clinically perceptible discoloration of the immersed materials apart from the MTA Plus mixed with distilled water. No statistically significant difference was detected regarding the type of mixing agent in the specimens immersed in either distilled water or EDTA ( $p>0.05)$.

All of the tested materials showed clinically perceptible discoloration when they were immersed in $\mathrm{NaOCl}$ solution. MTA Plus mixed with distilled water showed significantly greatest discoloration after contact with $\mathrm{NaOCl}(p<0.05)$. Mixing with distilled water significantly increased the $\triangle \mathrm{E}$ value of MTA Plus and NeoMTA Plus compared to mixing with gel $(p<0.05)$. MTA Plus mixed with gel showed the highest color stability regardless of the solution type.

\section{Discussion}

The present study evaluated the effect of the mixing agents on the color stability of 2 novel calcium silicate-based materials, as MTA Plus and NeoMTA Plus in contact with different irrigation solutions. Irrigation is an indispensible phase of root canal disinfection and $\mathrm{NaOCl}$ has been a standard irrigant for disinfection procedures and cannot be eliminated from the

Table 1. Mean and standard deviation values of materials' color changes $(\Delta E)$ after immersion of different irrigation solutions

\begin{tabular}{|l|l|l|l|}
\hline & Distilled water & EDTA (17\%) & Sodium hypochlorite (5\%) \\
\hline MTA Plus + distilled water & $4.02 \pm 0.24^{\mathrm{Aa}}$ & $5.76 \pm 0.69^{\mathrm{Aa}}$ & $35.64 \pm 5.42^{\mathrm{Ba}}$ \\
\hline MTA Plus + gel & $3.10 \pm 1.84^{\mathrm{Aa}}$ & $5.07 \pm 3.59^{\mathrm{Aa}}$ & $18.22 \pm 0.35^{\mathrm{Bb}}$ \\
\hline NeoMTA Plus + distilled water & $3.20 \pm 0.05^{\mathrm{Aa}}$ & $4.92 \pm 1.52^{\mathrm{Aa}}$ & $12.92 \pm 2.85^{\mathrm{BC}}$ \\
\hline NeoMTA Plus + gel & $1.87 \pm 0.69^{\mathrm{Aa}}$ & $1.93 \pm 0.78^{\mathrm{Aa}}$ & $6.91 \pm 2.89^{\mathrm{Bd}}$ \\
\hline
\end{tabular}

Different superscript lower letters in the same column show statistically significant difference $(p<0.05)$. Different superscript capital letters in the same line show statistically significant difference $(p<0.05)$

EDTA: Ethylenediaminetetraacetic acid, MTA: Mineral trioxide aggregate 
treatment protocol. Avoidance of the contact of $\mathrm{NaOCl}$ and the applied material or the use of a material that will provide color stability in contact with $\mathrm{NaOCl}$ are precautions for possible discoloration. However, avoidance of contact with $\mathrm{NaOCl}$ does not seem realistic. In our study, set specimens were immersed in irrigation solutions for 24 hours. Since, $\mathrm{NaOCl}$ has been reported to crystallize and occlude dentinal tubules; it could not be completely eliminated from root canal system (14). Residual $\mathrm{NaOCl}$ within tubules might come into contact with chlorhexidine gluconate as well as with calcium silicate-based materials during regenerative endodontic applications or during the repair of resorption cavities and the management of perforations. Prolonged immersion into irrigation solutions are preferred to simulate this long contact duration of the solution and calcium silicate-based materials in the root canal system.

Visual inspection and the use of specific devices have been utilized for the measurement of color changes of dental materials. CIE system is an ISO acknowledged system for international standardization of color change measurement (15). Instrumental measurements of color change using the CIE system include the use of colorimeters and spectrophotometers. Visual spectrophotometry has been regarded as a gold standard technique (16). In the present study, spectrophotometric analysis was preferred due to the technique's sensitivity, instrument's objectivity and repeatability (13).

MTA Plus consists of bismuth oxide as radiopacifier, whereas NeoMTA Plus consists tantalum oxide. Contact of bismuth oxide with $\mathrm{NaOCl}$ has been reported to result in discoloration of the material $(17,18)$. Bismuth oxide discolors via two mechanisms depending on the environmental conditions. In the absence of oxygen, bismuth oxide has been reported to dissociate into metallic bismuth and oxygen when exposed to light $(19,20)$. However, previous studies have reported that bismuth oxide also discolors due to overoxidation as a result of their contact with $\mathrm{NaOCl}(16)$. Due to the oxidation process, the oxygen from bismuth oxide becomes unstable and reacts with the carbon dioxide in the air. This reaction produces bismuth carbonate, which is sensitive to light and lead discoloration
(21). A previous study evaluated the color stability of MTA Plus and NeoMTA Plus in contact with $\mathrm{NaOCl}$ and distilled water. Authors reported that MTA Plus discolored following contact with $\mathrm{NaOCl}$ and NeoMTA Plus exhibited color stability (22). In the present study contact of $\mathrm{NaOCl}$ and MTA Plus mixed either with distilled water and gel resulted in significantly greater discoloration than the contact of $\mathrm{NaOCl}$ and NeoMTA Plus. The findings of the present study were in accordance with the results of that study, since MTA Plus mixed with gel induced significant discoloration compared to NeoMTA Plus mixed with the same agent (17). The presence of bismuth oxide within MTA Plus powder could contribute to the higher $\Delta \mathrm{E}$ values of the material compared to NeoMTA Plus, which replaced bismuth oxide with zirconium oxide.

In the present study, contact with distilled water or EDTA did not significantly increase $\Delta E$ values of the materials irrespective of the mixing agents. Only the contact of EDTA with NeoMTA Plus mixed with gel did not resulted in clinically perceptible discoloration of the material, whereas contact of EDTA with the other materials exceeded 3.3 $\Delta \mathrm{E}$ threshold values. However, the differences were not statistically significant.

In the present study, contact with $\mathrm{NaOCl}$ and MTA Plus mixed with distilled water led to significantly greater discoloration than MTA Plus mixed with the gel. MTA Plus has been reported to have a finer particle size than the ProRoot MTA, which is further associated with higher ion release, porosity, solubility, and water sorption when compared to the ProRoot MTA $(12,23)$. These properties enhance the ability of the MTA Plus to release calcium and prolong the bioactivity of the material (23). However, certain physical properties, such as the increased porosity, fluid uptake, and sorption values, were also correlated with bloodinduced discoloration in a recent study (24). In this study, the staining agents, such as blood, which could be absorbed by the material's surface, were not used. Direct comparison could not be made because no other study has evaluated the effect of mixing agent on the color stability of MTA Plus or NeoMTA Plus. Distilled water, which was used as a mixing agent for materials might contribute increased discoloration via structural surface changes. The fluid uptake ability 
and surface porosity of the MTA Plus and NeoMTA Plus might increase when mixed with distilled water instead of the gel and lead to discoloration after contact with $\mathrm{NaOCl}$.

Previous literature suggests the application of a double layer dentin bonding material on the access cavity or treatment with internal bleaching to prevent discoloration caused by calcium silicate-based materials $(25,26)$.

\section{Conclusions}

Within the limitations of this study, mixing with distilled water negatively affects the color stability of MTA Plus and NeoMTA Plus materials in contact with $\mathrm{NaOCl}$. Anti-washout gel also contributed to the color stability of the materials.

\section{Ethics}

Ethical Committee Approval: The study did not include any human or animal information, tissue or material. Thus, no ethical approval was required.

Informed Consent: The study did not include any human. Thus, informed consent was not required.

Peer-review: Externally peer-reviewed.

\section{Authorship Contributions}

Concept: C.K., E.S., Design: C.K., E.S., Data Collection or Processing: E.S., Analysis or Interpretation: C.K., Literature Search: C.K., Writing: C.K., E.S.

Conflict of Interest: The authors declare that they have no conflict of interest.

Financial Disclosure: The authors declare that they have no financial interests.

\section{References}

1. Van der Burgt T, Mullaney T, Plasschaert A. Tooth discoloration induced by endodontic sealers. Oral Surg Oral Med Oral Pathol 1986; 61: 84-9.

2. Davis MC, Walton RE, Rivera EM. Sealer distribution in coronal dentin. J Endod 2002; 28: 464-6.

3. Torabinejad $M$, White DJ. Tooth filling material and method of use. In.: Google Patents; 1995.

4. Torabinejad M, Chivian N. Clinical applications of mineral trioxide aggregate. J Endod 1999; 25: 197-205.

5. Chen MH, Chen KL, Chen CA, Tayebaty F, Rosenberg P, Lin L. Responses of immature permanent teeth with infected necrotic pulp tissue and apical periodontitis/abscess to revascularization procedures. Int Endod J 2012; 45: 294-305.

6. Antunes Bortoluzzi E, Sivieri Araújo G, Maria Guerreiro Tanomaru J, Tanomaru-Filho M. Marginal gingiva discoloration by gray MTA: a case report. J Endod 2007; 33: 325-7.

7. Karabucak B, Li D, Lim J, lqbal M. Vital pulp therapy with mineral trioxide aggregate. Dent Traumatol 2005;21:240-3.

8. Glickman GN, Koch KA. 21st-century endodontics. JADA 2000; 131: 39-46.

9. Watts JD, Holt DM, Beeson TJ, Kirkpatrick TC, Rutledge RE. Effects of $\mathrm{pH}$ and mixing agents on the temporal setting of toothcolored and gray mineral trioxide aggregate. J Endod 2007; 33: 970-3.

10. Jacobovitz M, De Lima R. Treatment of inflammatory internal root resorption with mineral trioxide aggregate: a case report. Int Endod J 2008; 41: 905-12.

11. Jacobovitz M, De Pontes Lima RK. The use of calcium hydroxide and mineral trioxide aggregate on apexification of a replanted tooth: a case report. Dent Traumatol 2009; 25: 32-6.

12. Camilleri J, Formosa L, Damidot D. The setting characteristics of MTA Plus in different environmental conditions. Int Endod J 2013; 46: 831-40.

13. Khokhar Z, Razzoog M, Yaman P. Color stability of restorative resins. Quintessence Int 1991; 22-5.

14. Gutiérrez JH, Guzmán M. Tooth discoloration in endodontic procedures. Oral Surg Oral Med Oral Pathol 1968; 26: 706-11.

15. Ioannidis K, Mistakidis I, Beltes P, Karagiannis V. Spectrophotometric analysis of coronal discolouration induced by grey and white MTA. Int Endod J 2013; 46: 137-44.

16. Sproull RC. Color matching in dentistry. Part II. Practical applications of the organization of color. J Prost Dent 1973; 29: 556-66.

17. Camilleri J. Color stability of white mineral trioxide aggregate in contact with hypochlorite solution. J Endod 2014; 40: 436-40.

18. Keskin C, Demiryurek EO, Ozyurek T. Color stabilities of calcium silicate-based materials in contact with different irrigation solutions. J Endod 2015; 41: 409-11.

19. Felman D, Parashos P. Coronal tooth discoloration and white mineral trioxide aggregate. J Endod 2013; 39: 484-7.

20. Vallés M, Mercadé M, Duran-Sindreu F, Bourdelande JL, Roig M. Influence of light and oxygen on the color stability of five calcium silicate-based materials. J Endod 2013; 39: 525-8.

21. Kang SH, Shin YS, Lee HS, Kim SO, Shin Y, Jung IY, et al. Color changes of teeth after treatment with various mineral trioxide aggregate-based materials: an ex vivo study. J Endod 2015; 41: 737-41.

22. Camilleri J. Staining potential of Neo MTA Plus, MTA Plus, and Biodentine used for pulpotomy procedures. J Endod 2015; 41: 1139-45. 
23. Gandolfi MG, Siboni F, Primus CM, Prati C. Ion release, porosity, solubility, and bioactivity of MTA Plus tricalcium silicate. J Endod 2014; 40: 1632-7.

24. Yoldaş SE, Bani M, Atabek D, Bodur H. Comparison of the Potential Discoloration Effect of Bioaggregate, Biodentine, and White Mineral Trioxide Aggregate on Bovine Teeth: In Vitro Research. J Endod 2016; 42: 1815-8.
25. Akbari M, Rouhani A, Samiee S, Jafarzadeh H. Effect of dentin bonding agent on the prevention of tooth discoloration produced by mineral trioxide aggregate. Int J Dent 2012; 2012: 563203.

26. Belobrov I, Parashos P. Treatment of tooth discoloration after the use of white mineral trioxide aggregate. J Endod 2011; 37: 1017-20. 